\title{
Analytical Method Development and Validation of Exemestane Tablet by UV Spectrophotometry
}

\author{
*S. ANGALAPARAMESWARI, V. S. THIRUVENGADARAJAN, \\ N. AMRUTH KUMAR, M. KUTUMBARAO, S. RAMKANTH, AND \\ C. MADHUSUDHANACHETTY
}

\begin{abstract}
Department of Pharmaceutical Analysis, Annamacharya College of Pharmacy Rajampet 516 126, Kadapa district, Andhra Pradesh. India

eswarialagusundaram@gmail.com
\end{abstract}

Received 02 November 2011; Accepted 07 January 2012

\begin{abstract}
The present research work discusses the development and validation of a UV spectrophotometric method for Exemestane. Simple, accurate and cost efficient spectrophotometric method has been developed for the estimation of Exemestane in Tablet dosage form. The optimum conditions for the analysis of the drug were established. The maximum wavelength ( $\lambda$ max) was found to be $246 \mathrm{~nm}$. The percentage recovery of Exemestane was in the $98.7 \pm 0.4$. Beers law was obeyed in the concentration range of $2-14 \mu \mathrm{g} / \mathrm{mL}$. Calibration curves shows a linear relationship between the absorbance and concentration. The line equation $y=0.05954 x+0.0000$ with $r^{2}$ of 0.9938 was obtained. Validation was performed according to ICH guidelines for Linearity, accuracy, precision, LOD and LOQ. The sample solution was stable up to 36 hours. The proposed method may be suitable for the analysis of Exemestane in tablet formulation for quality control purposes.
\end{abstract}

Key word: Exemestane, validation, precision, accuracy, LOQ, LOD, ICH guidelines.

\section{Introduction}

Aromatase is one of the first molecular targets for rational drug development in the treatment of cancer ${ }^{1}$. Aromatase is present in breast tissue and intratumoral aromatase is the source of local estrogen production in breast cancer tissues. Inhibition of aromatase is an important approach for reducing growth-stimulatory effects of estrogents in estrogen dependent breast cancer. Aromatase inhibitors are more effective than tamoxifen in post menopausal women with metastatic estrogen dependent breast cancer ${ }^{2}$. Exemestane is a third generation steroidal inhibitor of aromatase inhibitor ${ }^{3}$.

Exemestane is not official in any of the pharmacopoeia and the USP pending monograph was available. Very few methods are available for the estimation of exemestane 
and its related products. Burcin Yavuz et al., (2007) were developed HPLC method for the determination of exemestane in oral anticancer drugs ${ }^{4}$. S Persiani et al., (1995) was performed the determination of exemestane in biological fluids by HPLC followed by radioimmune assay ${ }^{5}$. Most of these methods are uneconomic and involving complex sample preparation ${ }^{6-8}$. So, there is a need for the development of simple sensitive effective and economic methods and hence the present work was planned to validate the UV spectroscopic method for exemestane in tablet formulations by using following parameter like accuracy, precision, linearity and range, limit of detection, limit of quantification, specificity, robustness, ruggedness and system suitability as per ICH guidelines ${ }^{9-12}$. The aim of present work is to find out a simple, sensitive, specific, spectrophotometric method for the detection of Exemestane in pharmaceutical tablet formulation.

\section{Experiment}

Exemestane (Gift sample by Tocris bioscience (Missouri, USA), Methanol A.R grade were purchased from Qualigens Fine Chemicals, New Delhi. UV-Visible double beam spectrophotometer (UV-1800, SHIMADZU Limited, Japan) with $1 \mathrm{~cm}$ matched quartz cells, Micropipette of Variable volume 10-1000 $\mu \mathrm{L}$ (Gene Pete Co.) and Digital balance (Axis LC)

\section{Method Development}

Standard Exemestane $(10 \mathrm{mg})$ was accurately weighed and transferred to $10 \mathrm{~mL}$ volumetric flask. It was dissolved properly and diluted up to the mark with methanol to obtain concentration of $1 \mathrm{mg} / \mathrm{mL}$. This solution was used as working standard solution. From this solution, by suitably dilution, $5 \mu \mathrm{g} / \mathrm{mL}$ concentrations was obtained and used as standard solution. For calibration curve, dilution was made from $100 \mu \mathrm{g} / \mathrm{mL}$. The absorbance of the solutions containing Exemestane at $5 \mu \mathrm{g} / \mathrm{mL}$ was determined in the UV range $200-400 \mathrm{~nm}$ using an appropriate blank. The $\lambda$ max was found to be $246 \mathrm{~nm}$ (Table 1). At these wavelength maxima, calibration curve was drawn by plotting graph between absorbance and concentrations (Figure 1).

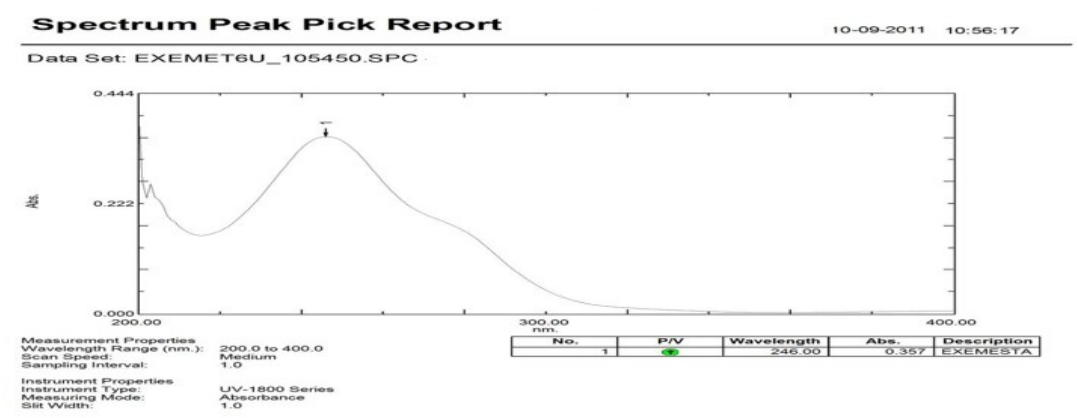

Figure 1. Absorption Maxima of Standard Exemestane. 
Table 1. Calibration Curve Parameter.

\begin{tabular}{|c|c|}
\hline Concentration $\mu \mathrm{g} / \mathrm{mL}$ & Absorbance \\
\hline 2 & 0.119 \\
\hline 4 & 0.239 \\
\hline 6 & 0.347 \\
\hline 8 & 0.437 \\
\hline 10 & 0.622 \\
\hline 12 & 0.704 \\
\hline 14 & 0.850 \\
\hline
\end{tabular}

\section{Validation of Method Parameters}

\section{Linearity}

The aliquots of concentration ranging $2-14 \mu \mathrm{g} / \mathrm{mL}$ were prepared in triplicate, but linearity was found to be between $2-10 \mu \mathrm{g} / \mathrm{mL}$ concentrations. The linearity was calculated by the least square regression method (Table 2).

Table 2. Validation Parameters.

\begin{tabular}{|c|c|c|}
\hline S. No & Parameter & Result \\
\hline 1. & Absorption Maxima $(\mathrm{nm})$ & 246 \\
\hline 2. & Linearity Range $(\mu \mathrm{g} / \mathrm{mL})$ & $\mathrm{y}=0.05954 \mathrm{x}+0.0000$ \\
\hline 3. & Standard Regression Equation & 0.9938 \\
\hline 4. & Correlation Coefficient $\left(\mathrm{R}^{2}\right)$ & $98.7 \pm 0.4$ \\
\hline 5. & Accuracy $(\%$ Recovery $\pm \mathrm{SD})$ & 1.14 \\
\hline 6. & $\mathrm{LOD} \mu \mathrm{g} / \mathrm{mL}$ & 3.47 \\
\hline 7. & $\mathrm{LOQ} \mu \mathrm{g} / \mathrm{mL}$ & 2 \\
\hline
\end{tabular}

\section{Precision}

The precision of the assay was determined by repeatability (intraday) and intermediate precision (inter-day) and reported as RSD \%. For this, $3.5 \mu \mathrm{g} / \mathrm{mL}, 5.5 \mu \mathrm{g} / \mathrm{mL}$ and $7.5 \mu \mathrm{g} / \mathrm{mL}$ concentration solution was measured three times in day and RSD\% was calculated. (Table 3) 
Table 3. Results of Recovery and Precision.

\begin{tabular}{|l|c|c|c|c|c|c|}
\hline Ingredient & $\begin{array}{c}\text { Amount of } \\
\text { drug from } \\
\text { formulation } \\
\mu \mathrm{g} / \mathrm{mL}\end{array}$ & $\begin{array}{c}\text { Amount } \\
\text { Added } \\
\mu \mathrm{g} / \mathrm{mL}\end{array}$ & $\begin{array}{c}\text { Amount } \\
\text { Recovered } \\
\mu \mathrm{g} / \mathrm{mL}\end{array}$ & $\begin{array}{c}\% \\
\text { Recovery* }\end{array}$ & $\begin{array}{c}\text { Precision } \\
\text { (Intra } \\
\text { Day)* }\end{array}$ & $\begin{array}{c}\text { Precision } \\
\text { (Inter } \\
\text { Day)* }\end{array}$ \\
\hline Exemestane & 4 & 3.5 & 3.504 & 99.88 & 0.732 & 0.480 \\
\hline Exemestane & 4 & 5.5 & 5.447 & 99.03 & 0.470 & 0.777 \\
\hline Exemestane & 4 & 7.5 & 7.525 & 100.03 & 0.223 & 0.932 \\
\hline * Percentage RSD of Three Samples.
\end{tabular}

Accuracy (Recovery)

The accuracy of the method was evaluated through standard addition method. In this, known amount of standard Exemestane was added in pre-analyzed sample. This was done for $3.5 \mu \mathrm{g} / \mathrm{mL}, 5.5 \mu \mathrm{g} / \mathrm{mL}$ and $7.5 \mu \mathrm{g} / \mathrm{mL}$ and in triplicate. (Table 3)

\section{Stability}

The standard stock solutions of Exemestane concentration $5.5 \mu \mathrm{g} / \mathrm{mL}$ was subjected to heat treatment on $40^{\circ} \mathrm{C}, 50^{\circ} \mathrm{C}$ and absorbance were measured. The absorbance for $40^{\circ} \mathrm{C}$ for $1 \mathrm{hr}$ was same while for $50^{\circ} \mathrm{C}$, the absorbance was decreasing which was indicative that Exemestane is stable at $40^{\circ} \mathrm{C}$ and but at $50^{\circ} \mathrm{C}$ Exemestane solutions unstable.

\section{Sample Preparation}

The proposed method was applied to analyze commercially available Exemestane tablets. The tablet was having content of Exemestane equivalent to $80 \mathrm{mg}$. Twenty tablets were weighed and weight equivalent to $80 \mathrm{mg}$ was dissolved in methanol. By frequent shaking volume was made up to mark methanol. The solution was then filtered through Whattman filter paper \#41. The filtrate was diluted suitably with solvent to get the solution of $4 \mu \mathrm{g} / \mathrm{mL}$ concentration. The absorbance was measured against solution blank. Amount of Exemestane was calculated from the calibration curve. The readings were taken in triplicate by performing the same experimentation in three times.

\section{Result and Discussion}

In the start of the method development for this drug, different solvents were tested such as ethanol, chloroform, acetone, $0.1 \mathrm{~N} \mathrm{HCl}, 0.1 \mathrm{~N} \mathrm{NaOH}$ and methanol. Due to greater solubility and reproducible readings of maximum absorbance, methanol was taken under consideration for further work. By serial dilution of $100 \mu \mathrm{g} / \mathrm{mL}$, the different dilutions of standard drug having concentration $2,4,6,8,10,12$ and $14 \mu \mathrm{g} / \mathrm{mL}$ were prepared and calibration curve was prepared by plotting graph between absorbance and concentration $(\mu \mathrm{g} / \mathrm{mL})$ (Figure 2). The results of linearity are presented in table 2 . The data was statistically validated by means of least square regression method. The detection and quantization limits as LOD $(\mathrm{k}=3.3)$ and LOQ $(\mathrm{k}=10)$ were calculated and these were found to be $1.14 \mu \mathrm{g} / \mathrm{mL}$ and $3.47 \mu \mathrm{g} / \mathrm{mL}$ respectively. The precision (measurements of intraday and interday) results showed good 
reproducibility with percentage relative standard deviation (\% RSD) is below 2.0. This indicated that method is highly precise.

Table 4. Determinations of Active Ingredients in Tablets.

\begin{tabular}{|c|c|c|c|}
\hline Sample & Label Claim & Amount Found mg /Tab*. & \% Labelled Claim* \\
\hline Exemestane & 25 & 24.7 & 98.87 \\
\hline * Average of Three Determinations. \\
\hline
\end{tabular}

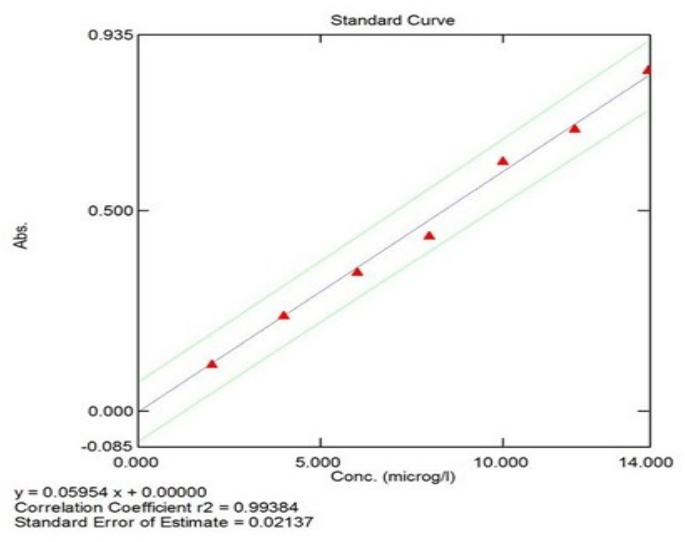

\begin{tabular}{|c|c|c|c|c|c|c|c|c|}
\hline & Sample ID & Type & Date & Time & Conc & WL246.0 & Wgtfactor & Comments \\
\hline 1 & STD1 & Standard & 177.09 .2011 & $16: 18: 16$ & 2000 & 0.119 & 1.000 & \\
\hline 2 & STD2 & Standard & 17:09.2011 & 16.18 .27 & 4.000 & 0.239 & 1.000 & \\
\hline 3 & STDS & Standard & 17.09.2011 & 162300 & 8.000 & 0.347 & 1.000 & \\
\hline 4 & STO4 & Standard & 17.09.2011 & 1624.58 & 8.000 & 0.437 & 1.000 & \\
\hline 5 & STDS & Standard & $177.09 \cdot 2011$ & 1626.18 & 100000 & 0.622 & 1.000 & \\
\hline 6 & STDB & Standard & 177.09 .2011 & 1627.07 & 12000 & 0.704 & 1.000 & \\
\hline \begin{tabular}{|ll}
7 \\
\end{tabular} & \begin{tabular}{|l|} 
STD7 \\
\end{tabular} & Standard & $17.09 \cdot 2011$ & 1628.10 & 14000 & 0.850 & 1.000 & \\
\hline 8 & & & & & & & & \\
\hline
\end{tabular}

Sample Table
\begin{tabular}{|l|c|c|c|c|r|r|r|}
\hline & Sample ID & Type & Date & Time & \multicolumn{1}{c|}{ Conc } & WL2 246.0 & Comments \\
\hline 1 & SAMPLE & Unknown & 17.09 .2011 & 16.31 .31 & 4.149 & 0.247 & \\
\hline 2 & & & & & & & \\
\hline
\end{tabular}

Figure 2: Calibration Curve of Standard Exemestane.

The evaluation of accuracy of the method was performed by standard addition method. The test solution was prepared as $4 \mu \mathrm{g} / \mathrm{mL}$ with the addition of $3.5 \mu \mathrm{g} / \mathrm{mL}, 5.5 \mu \mathrm{g} / \mathrm{mL}$ and $7.5 \mu \mathrm{g} / \mathrm{mL}$ concentrations standard solution was added and recovery was found to be $98.7 \%$. This indicated accuracy of proposed method.

The proposed method was also applied for the assay of Exemestane in tablet formulation (in triplicate) and the results as tabulated in Table 4. The results obtained were good agreement with the label claims. 


\section{Conclusion}

From the results and discussion the method described in this paper for the determination of Exemestane from tablet formulation is simple, accurate, sensitive and reproducible. The proposed methods can be successfully applied for Exemestane assay in tablet dosage forms without any interference in quality control. Analysis of the tablets by this method were reproducible reliable and in good agreement with label claim of the drug.

\section{References}

1. Ian E Smith and Mitch Dowsett, N Engl J Med, 2003, 348, 2431-2442.

2. Brueggemeier RW, Am J Ther. 2001, 8(5), 333-44.

3. Susana M. Campos, The Oncologist, 2004, 9(2), 126-136.

4. Burcin Yavuz, Erem Bilensoy and Murat Summufabad, Burcin Journal of Pharma science, 2007, 32, 15-22.

5. S. Persini, European Journal of Pharmaceutical Sciences, 1996, 4(6), 331-340.

6. Per E. Lonning, Jurgen Geisler, Lars E. Krag, Bjørn Erikstein, Yngve Bremnes, Anne I. Hagen Ellen Schlichting, Ernst A. Lien, Erik S. Ofjord, Jolanda Paolini, Anna Polli, and Giorgio Massimini, Journal of Clinical Oncology, 2005, 23(22), 5126-5137.

7. V Cenachi, S Baratte, P Cicioni, E Frigerio, J Long and C James, J Pharm Biomed Anal. 2000; 22(3), 451-60.

8. Giuseppe corona, Caterina Elia, Bruno Castta, Crivellari Diana, Sara Rosalen, Mario Bari and Giuseppe Toffoli, J Mass Spectrom, 2009 Jun; 44(6), 920-928.

9. J. Vessman, J. Pharm and Biomed. Anal., 1996; 14, 867 - 869.

10. ICH, QIA Stability Testing of New Drug Substances and Products, Int. Conf on Harmonization, Geresa, November 1996.

11. International conference on Harmonisation, Guidance for Industry in Q2B validation on analytical procedures: methodology. Switzerland IFPMA; 1996, 1-8.

12. Wegscheider, Validation of Analytical Methods, in: Accreditation and Quality Assurance in Analytical Chemistry, H. Guenzler, Springer (Ed.) Verlag, Berlin 1996. 


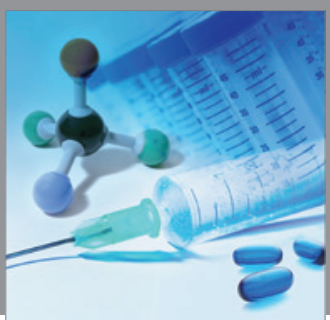

International Journal of

Medicinal Chemistry

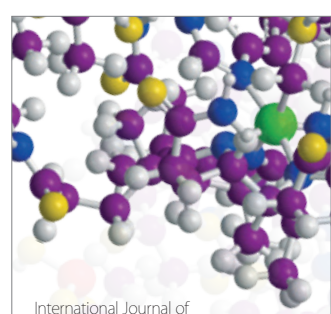

Carbohydrate Chemistry

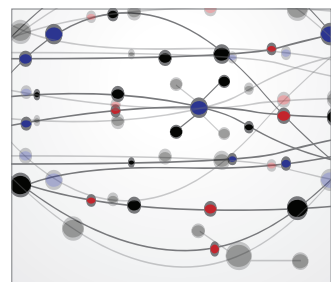

The Scientific World Journal
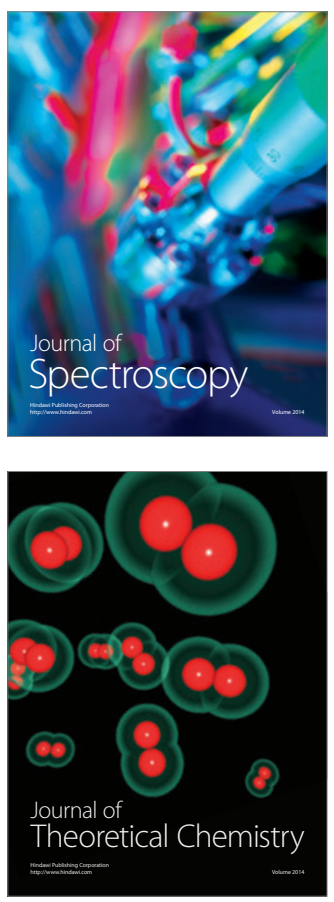
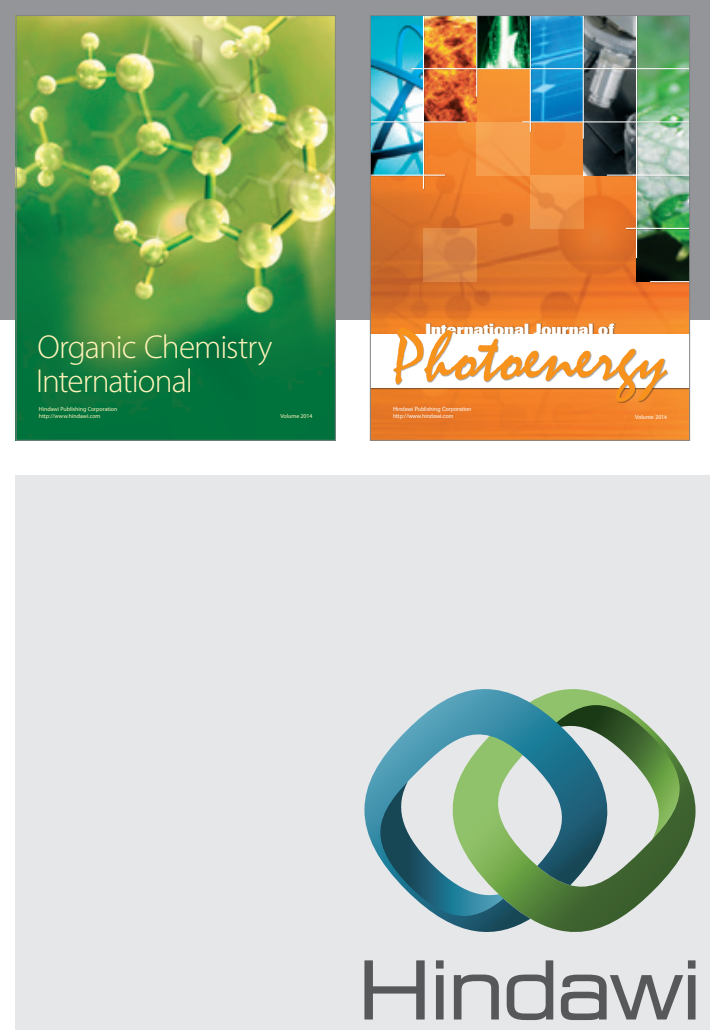

Submit your manuscripts at

http://www.hindawi.com
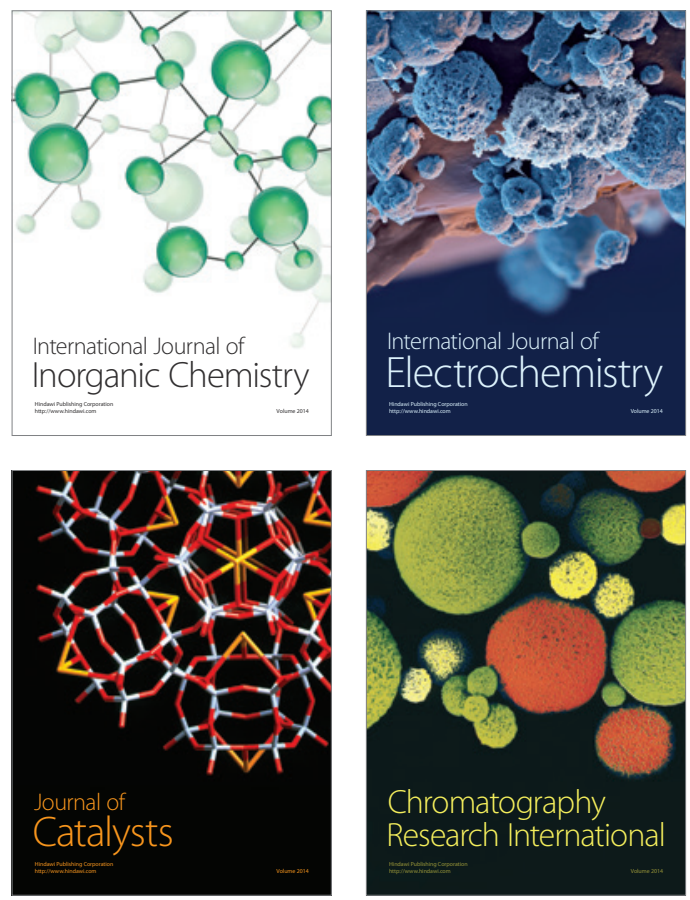
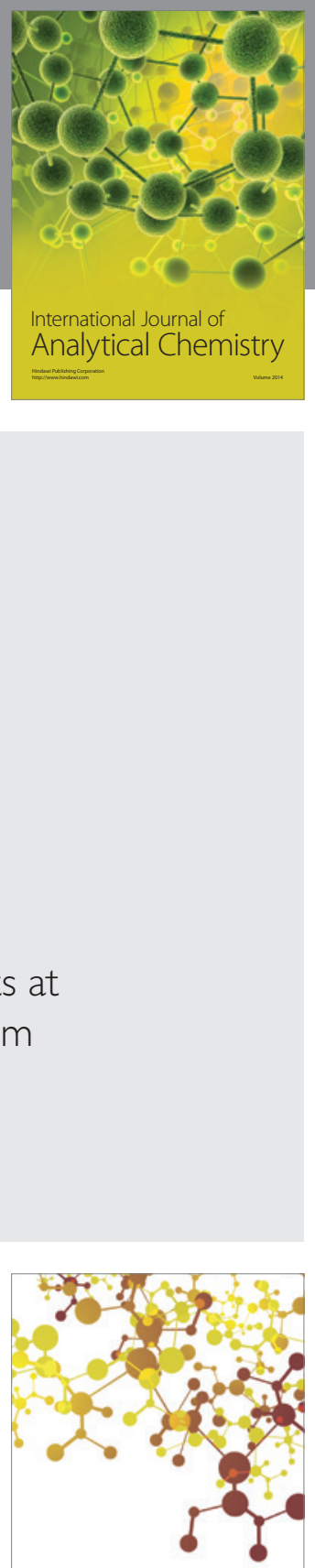

Journal of

Applied Chemistry
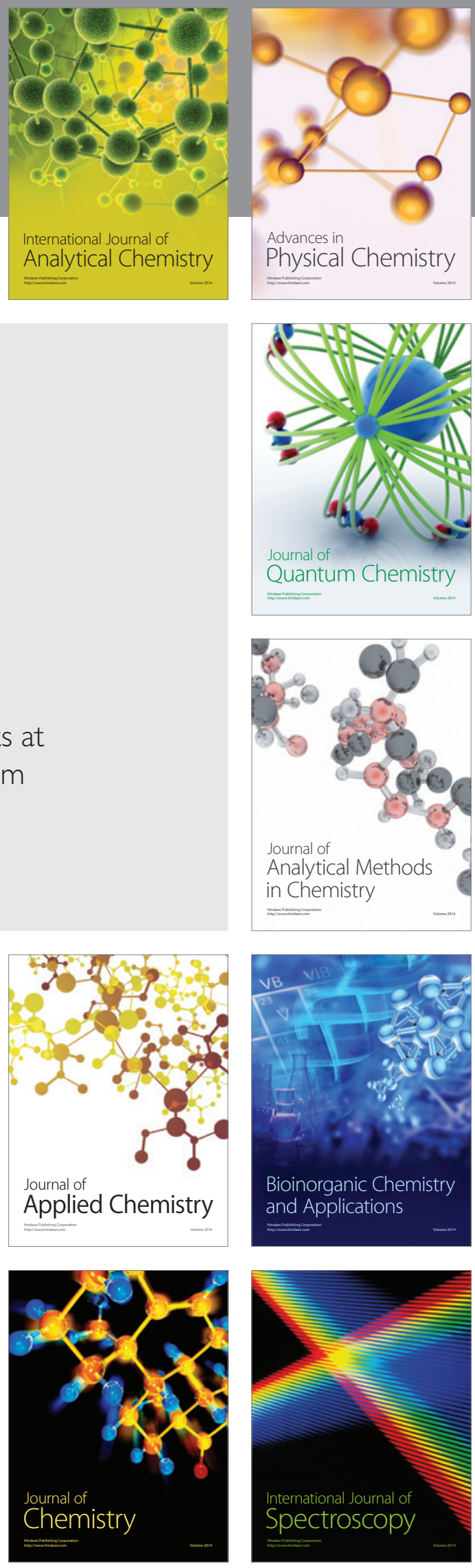